\title{
Function of Indravati in the Management of Diabetes - an Analytical Classical Review
}

\author{
${ }^{1}$ Dr. Om Prakash Panwar, ${ }^{2}$ Dr. Suparna Saha, ${ }^{3}$ Dr.Rajendra Prasad Sharma, ${ }^{4}$ Dr. Parimi Suresh, \\ ${ }^{5}$ Dr.K. Shankar Rao \\ ${ }^{1,2}$ MD scholar, Dept. of Rasashastra\&bhaisajyakalpana, NIA, Jaipur \\ ${ }^{3}$ Assistant Professor, Dept.of Rasashastra\&bhaisajyakalpana, NIA, Jaipur \\ ${ }^{4}$ Professor, Dept.of Rasashastra\&bhaisajyakalpana, NIA, Jaipur \\ ${ }^{5}$ Professor, Head of the Dept. of Rasashastra\&bhaisajyakalpana, NIA, Jaipur
}

Correspondence address: Dr. Om PrakashPanwar

Dept.of Rasashastra\&bhaisajya kalpana, NIA, Jaipur

P.G. Dept. of Rasashastra and Bhaishajya Kalpana.National Institute of Ayurveda

\begin{abstract}
:
Rasoushadies; the organometallic formulations have been in use in the treatment of diabetes with their excellence for centuries. But now-a-days it has become necessary to allay the prevailing notions regarding safety and efficacy of Rasoushadis. Indravati is one of such excellent herbomineral preparation described in the Rasendrasarasangrahpramehadhikara. Content of Indravati are MritaParad (Rasa sindoora) ,Vangabhasma, Arjuna Twak Churna, Shalmallimoolakwatha etc. In the present paper detail review of indravati and its role in the management of diabetes will be given.
\end{abstract}

Key words: Indravati, Vangabhasma, Madhumeha, Rasasindur

\section{Introduction:}

Ayurveda is science of life, which is a prestigious gift to the mankind. Rasachikitsa can consider as a backbone of Ayurvedachikitsa. Ancient times it was also known as daivichikitsa or rasaushadhichikitsa. Diabetes mellitus is a group of metabolic disease with multifactorial etiology. The disorder is as ancient as mankind .Diabetes is prevalent in all countries throughout the world.

In ayurveda this classical condition is elaborately dealt, under the heading of prameha .Madhumeha is one sub type of prameha, which is said to be incurable ,and it resembles closely to Diabetes mellitus.

Madhumeha can be correlated with diabetes mellitus.

DM-Chronic metabolic disorder characterised by hyperglycemia with or without glycosuria, resulting from an absolute or relative deficiency of insulin.

Rasashastra deals with the pharmaceutical and therapeutic uses of the different preparation of mercury,mineral and metals characterized by their small dosage, quick effectiveness, long durability etc. So Rasashastra has achieved the place of supreme importance in Ayurvedic medicine. In classical Rasa shastra text mentioned four types of mercurial preparations. i.e. Kharaliya, Parpati, Pottali, and kupipakwa.

\section{Material And Methods:}

The references regarding the drug scattered across the Classics of RasaShastra and the scientific Data available in the reputed journals will be compiled, arranged in systemic fashion. 
${ }^{1}$ Dr. O.P. Panwar, International Journal of Ayurvedic\& Herbal Medicine 7(6) Nov.-Dec. 2017 (2939-2941)

\section{Textual references of the drug :}

Indravatiras is a herbomineral and kharaliya preparation of Rasa shastraindiacated for prameha and especially for madhumeha initially it is described by Rasendrachintamani ,Bhaishajyaratnavali, Rasendrasarasamgraha, Rasa manjari, Rasakamdhenu etc. In all these Rasa shastra texts Indravati was mentioned under Pramehadhikara.

- Indravati is one of such excellent herbomineral preparation described in the Rasendrasarasangrahpramehadhikara. Content of Indravati are -

- Mrita Parad (Rasasindoora)

- Vangabhasma,

- Arjuna Twak Churna,

- Shalmallimoolakwatha etc.

Ingredients of indravati as mentioned in different texts:

\begin{tabular}{|c|c|c|c|c|c|c|c|}
\hline Text & Rasasindura & Vangabhasma & Arjunatwakchurna & Sugar & Bhavanadravya & Dose & Anupana \\
\hline Rasendrachintamani & + & + & + & + & $\begin{array}{c}\text { Shalmallimoola } \\
\text { kwatha }\end{array}$ & $\begin{array}{l}\text { Imasa } \\
162 \mathrm{mg}\end{array}$ & - \\
\hline Rasendrasarasangrah & + & + & + & - & Do & Do & - \\
\hline Rasa manjari, & + & + & + & + & Do & Do & - \\
\hline Rasakamdhenu & + & + & + & + & Do & Do & $\begin{array}{l}\text { Shalmolim } \\
\text { oolswaras }\end{array}$ \\
\hline Bhaishajyaratnavali & + & + & + & - & Do & Do & \\
\hline Rasa raja sundar & + & + & + & - & Do & Do & \\
\hline Rasa yogsagar & + & + & + & + & Do & Do & \\
\hline
\end{tabular}

\section{Result :}

\section{PharmacotherapeuticPropertiesof}

(1) Parad:

Rasa: shadrasa

Guna: Snigdha, Sara, Guru

Karma:Yogavahi, Rasayana, Vrishya, Vajikara, Dipana, Pushtikara, Ayushkara, Dehasiddhikara, Lohasiddhikara etc.

Doshaprabhava: Tridoshaghna.

Vyadhiprabhav: Jwara, Raktapitta, Kasa, Pandu, Prameha etc.

\section{(2) Gandhaka:}

Rasa:Katu,Tikta, Kashaya.

Guna: Snigdha,Sara.

Virya:Ushna.

Doshaprabhav: kapha and vatahara, pittakaraka.

Vyadiprabhav: kandu,kushta,Visarpa,Dadru,Krimi,Kasa,Shwasa etc.

(3) Vanga/Tin: Vangabhasmasignificantly controls the fasting blood sugar and post parendrial blood sugar levels in the patients of madhumeha. During treatment schedule it dose not show any adverse effect.

(4) Arjuna: Arjun has been used in Kaphajaprameha, Pittajapremeha and Atisara of kshaya.(Acc. to charakasamhita) 
${ }^{1}$ Dr. O.P. Panwar, International Journal of Ayurvedic\& Herbal Medicine 7(6) Nov.-Dec. 2017 (2939-2941)

Constituents of Arjuna: Bark contains tannin including glucotannic acid 45\%, a colouring matter, a glucosoidal body and ash $34 \%$ containing sodium, pure calcium carbonate and traces of alkaline chlorides.

\section{(5) Shalmali:}

Rasa: Madhura, kashaya.

Guna: Guru, Ruksha.

Virya: Sheeta

Vipaka: Madhura

Dosaprabhava: Mitigates pitta and Rakta.

Vyadhiprabhava: Atisara, Raktapradara, muthravikara, arbuda, shotha, raktajavikara etc.

\section{Root contain:}

Starch $-71.2 \%$

Sugars (arabinose and galactose) $-8.2 \%$

Moisture $-7.5 \%$

Peptic substances $-6 \%$

Mineral matter $-2.1 \%$

Cellulose $-2 \%$

Protein $-1.2 \%$

Fat $-0.9 \%$

Tannins $-0.4 \%$

Non tannins $-0.1 \%$

Root bark: Lupeol 2-sitostero 8-formyl-7-hydroxy 5-isopropyl 2-methoxy-3-3 methy-1,4 naphathaquinone

\section{Result :}

Indravati was proved clinically highly significant in previous research work as well as experimental study also done on this drug .

\section{Discussion :}

Indravatiis such a excellent drug which is very beneficial in diabetes. While the vangabhasmaactslike a antidiabetic mineral drug, thearjun , shalmaliswaras help to make a herbomineral drug which is more effective in human body. May be the rasasindur acts as a catalytic and potent ingredient of the Indravati.Some author added sugar in the preparation of this drug as acharyas were very well known about the symptoms of sudden occur hypogysemia during potent antidiabetic drug. So,the medicine is used rationally with proper dosing will be a panacea in madhumeha.

\section{Reference}

1. Jani et al, The role of media in the preparation of vangabhasma and evaluation for hypoglycemic and anti hyperglycemiceffect,MDayuthesis,Gujratayurveduniversity,Jamnagar 2008

2. Shastri G. Charaksamhita with vidhyotanihindi commentary chikitsasthana 4 ch.Reprinted.Varanasi: chaukhambaBhartiAcademy ;2004.

3. Quality standards of Indian medicinal plants.

4. S.K.M.K. Herapathdeniya, Study on indravatiras,BHU 